\title{
The Ecological Classification of Coastal Wet Longleaf Pine (Pinus palustris) of Florida from Reference Conditions
}

\author{
George L. McCaskill ${ }^{1}$, Shibu Jose ${ }^{2}$ \\ ${ }^{1}$ Forest Inventory \& Analysis, Northern Research Station, USDA Forest Service, Newtown Square, USA; ${ }^{2}$ Center for Agroforestry, \\ School of Natural Resources, University of Missouri, Columbia, USA. \\ Email: georgemccaskill@fs.fed.us
}

Received July $31^{\text {st }}, 2012$; revised August $28^{\text {th }}, 2012$; accepted September $10^{\text {th }}, 2012$

\begin{abstract}
Tropical storms, fire, and urbanization have produced a heavily fragmented forested landscape along Florida's Gulf coast. The longleaf pine forest, one of the most threatened ecosystems in the US, makes up a major part of this fragmented landscape. These three disturbance regimes have produced a mosaic of differently-aged pine patches of single or two cohort structures along this coastline. The major focus of our study was to determine reference ecosystem conditions by assessing the soil biochemical properties, overstory stand structure, and understory plant species richness along a patch-derived 110-year chronosequence in order to accurately evaluate on-going longleaf pine restoration projects. This ecological dataset was also used to classify each reference patch as mesic flatwoods, wet flatwoods, or wet savanna. All of the reference locations were found to have similar soil types with no significant differences in their soil biogeochemistry. Mean diameter-at-breast height (DBH), tree height, and patch basal area increased as mean patch age increased. Stand growth reached a plateau around 80 - 90 years. Shrub cover was significantly higher in the matureaged patches ( $86-110$ years) than in the young (6 - 10 years) or mid-aged (17 - 52 years) patches, despite prescribed fire. Plant species diversity as indicated by the Shannon-Wiener index decreased with patch age. Soil biogeochemical properties, forest structure, and understory species composition were effective for ecologically classifying our pine patches as $55 \%$ mesic flatwoods, $20 \%$ wet flatwoods, and $25 \%$ wet savanna. Florida's Gulf coastal wet longleaf pine flatwoods attain a structural and plant species equilibrium between 80 - 90 years.
\end{abstract}

Keywords: Forest Structure; Species Richness; Restoration; Pine Patches; Shannon-Wiener; Soil Biogeochemistry

\section{Introduction}

In recent years, there has been a great effort to restore longleaf pine (Pinus palustris Mill.) communities within the southeastern U.S. They are one of the most threatened ecosystems in the United States having less than 3\% of its original extent remaining [1]. Restoration projects have been implemented in an effort to restore more than 405,000 ha of longleaf pine in the Southeast during the past decade alone [2]. This effort continues with the goal to restore an additional 1,900,000 ha by 2015 [3].

Although many past studies have focused on the understory plant communities of longleaf pine ecosystems [4-7], less information exists on the spatial-temporal patterns of understory plant species as they relate to the soil biogeochemical properties and forest structure specifically situated within Florida's Gulf coastal flatwoods zone [8-10].

In addition, many researchers have classified longleaf pine sites along the lower Gulf coastal plain utilizing understory vegetation composition to separate one long- leaf pine site from another $[4,11,12]$. A few have used fluvial vs. upland descriptions, climatic conditions, soil drainage patterns, and differences in soil texture to classify differently structured longleaf pine stands [13-15].

\section{Coastal Wet Flatwoods}

Most of Florida's wet pine flatwoods are concentrated along the $1240 \mathrm{~km}$ Gulf coastline, which contains marshes, bays, and offshore islands. This coastal landscape is continuously shaped by active fluvial deposition and weather processes which promote and maintain the formation of beaches, swamps and wet mineral flats. The topographic relief ranges from 0 to $20 \mathrm{~m}$, the annual precipitation from $1300-1600 \mathrm{~mm}$, while the average annual temperature ranges between $19^{\circ} \mathrm{C}-21^{\circ} \mathrm{C}$. Growing seasons are long, lasting $270-290$ days [16]. Soil parent material consists of marine deposits containing limestone, marl, sand, and clay. The dominant suborders are Aquods, Aquents, and Aquepts, which are highly acidic poorly drained sandy soils having thermic and hyperthermic 
temperature regimes and an aquic moisture regime [1719].

In Florida, plant species richness increases with soil moisture until an ecotone between mesic pine flatwoods and Taxodium distichum swamps is reached [5,12,20,21]. This ecotone is occupied by wet flatwoods and wet savanna subtypes of the coastal pine flatwoods $[14,22,23]$. Their overstories are dominated with varying mixtures of Pinus palustris, Pinus elliottii, Pinus clausa var. immuginata), and/or Pinus serotina [24,25]. The herbaceous ground cover of longleaf pine flatwoods is very diverse due to the warm temperatures and high rainfall. Andropogon virginicus, Serenoa repens, Aristida stricta var. beyrichiana, Dichanthelium spp., Solidago odora, Rhexia alifanus, and Aster adnatus are found throughout all of the flatwoods types [26,27]. Where fire is restricted, Smilax pumila can be a prevalent vine species, especially on mature mesic sites [14]. Mesic longleaf pine flatwoods are also occupied by greater populations of oak species (Quercus pumila or laurifolia). Wet flatwoods have a greater presence of Lyonia lucida, Cliftonia monophylla, Nyssa sylvatica var. biflora, and Ilex glabra or coriacea. Wet pine savannas are distinguished from wet flatwoods by fewer overstory trees, and a greater abundance of Lachnanthes caroliniana, Cyperus, Scleria, Sarracenia, and Calopogon or Platanthera [23,26,27]. Wet pine flatwoods and wet savannas are defined as pinedominated, poorly drained, broad plain wetlands $[14,28$, 29], and represent more than one million ha in the Southeast [30]. There are almost 200 rare vascular plant taxa found in the various longleaf pine habitats of the Southeastern U.S. [5,12], with the majority of them being native to Florida where they are located in these wet pine flatwoods and their associated wetlands $[5,12,14$, $21,31]$.

Three disturbance regimes are important when identifying any pattern of structure or composition within coastal longleaf pine $[9,10,32,33]$. Hurricanes directly affect the canopy structure of longleaf pine stands through galeforced winds, opening up large tracts to sunlight and simplifying the structure and composition of the flora that occupy them [8]. The extensive flooding that accompanies the wind causes significant changes in both the above and below ground site productivity $[8,9,34]$. Fire impacts longleaf pine forests by reducing vegetative competition on regeneration through the removal of shrub size oaks and hickories [35]. Finally, anthropogenic effects from urban development, grazing, prescribed fire, and plantation forestry can reduce the structural complexity of forests and promote fragmentation within the landscape, reducing soil productivity and plant species diversity $[36,37]$.

The objectives of this study were to determine reference ecosystem conditions by assessing the soil bioche- mical properties, overstory stand structure, and understory plant species richness along a patch-derived 110year chronosequence in order to accurately evaluate ongoing longleaf pine restoration projects $[15,38]$. This ecological dataset was also used to classify each reference patch as mesic flatwoods, wet flatwoods, or wet savanna; while verifying similarities between each patch and conditions at restoration sites of the zone. The importance of this work centers on our ability to distinguish between the varieties of longleaf pine habitats found along Florida's Gulf in order to accurately assess their condition. We hypothesized that stand diameter-at-breast height (DBH), height, basal area (BA), and volume would increase while stand density and plant species richness would decrease when comparing younger pine patches with older ones. We also expected the majority of these parameters to reach a threshold ("plateau") as measured from within the older-aged patches [39].

\section{Materials and Methods}

\subsection{Study Sites}

Three reference locations were established within 3 kilometers of Florida's Gulf coastline. A strict coastal stratification was required to insure all of the reference locations would be exposed to similar weather conditions, specifically addressing the fact that Florida's Gulf lies within a very active hurricane zone $[8,15,40]$. The locations were Topsail Hill State Park, St. Marks National Wildlife Refuge, and the Chassahowitzka Wildlife Management Area of the Florida Fish and Game Commission (Figure 1). In addition to their coastal locations, these sites were selected because of the presence of certain plant communities, containing similar soil conditions, and having active longleaf pine restoration programs [15].

This narrow zone makes up the majority of the Natural Resource Conservation Service's Eastern Gulf Coast Flatwoods ecoregion (MLRA 152A) and the National Oceanic and Atmospheric Association's Panhandle Coast unit of the Louisianan reserve (National Estuary and River Reserve System). In addition, the Environmental Protection Agency (EPA) classifies this area as the Southern Coastal Plain (75) ecoregion, which was recently subdivided into the Gulf Coast Lowlands (75-01) and the Big Bend Karst (75-06) [41,42]. All of these federal designations make this coastal zone unique from an ecological as well as hydrological perspective.

All three sites have a soil moisture gradient as represented by mesic pine flatwoods, wet pine flatwoods, wet pine savannas, and Taxodium distichum swamps. Their common soils are described as sandy, siliceous, thermic, aeric, acidic, and poorly drained. All three sites have active longleaf pine restoration programs where fire has 


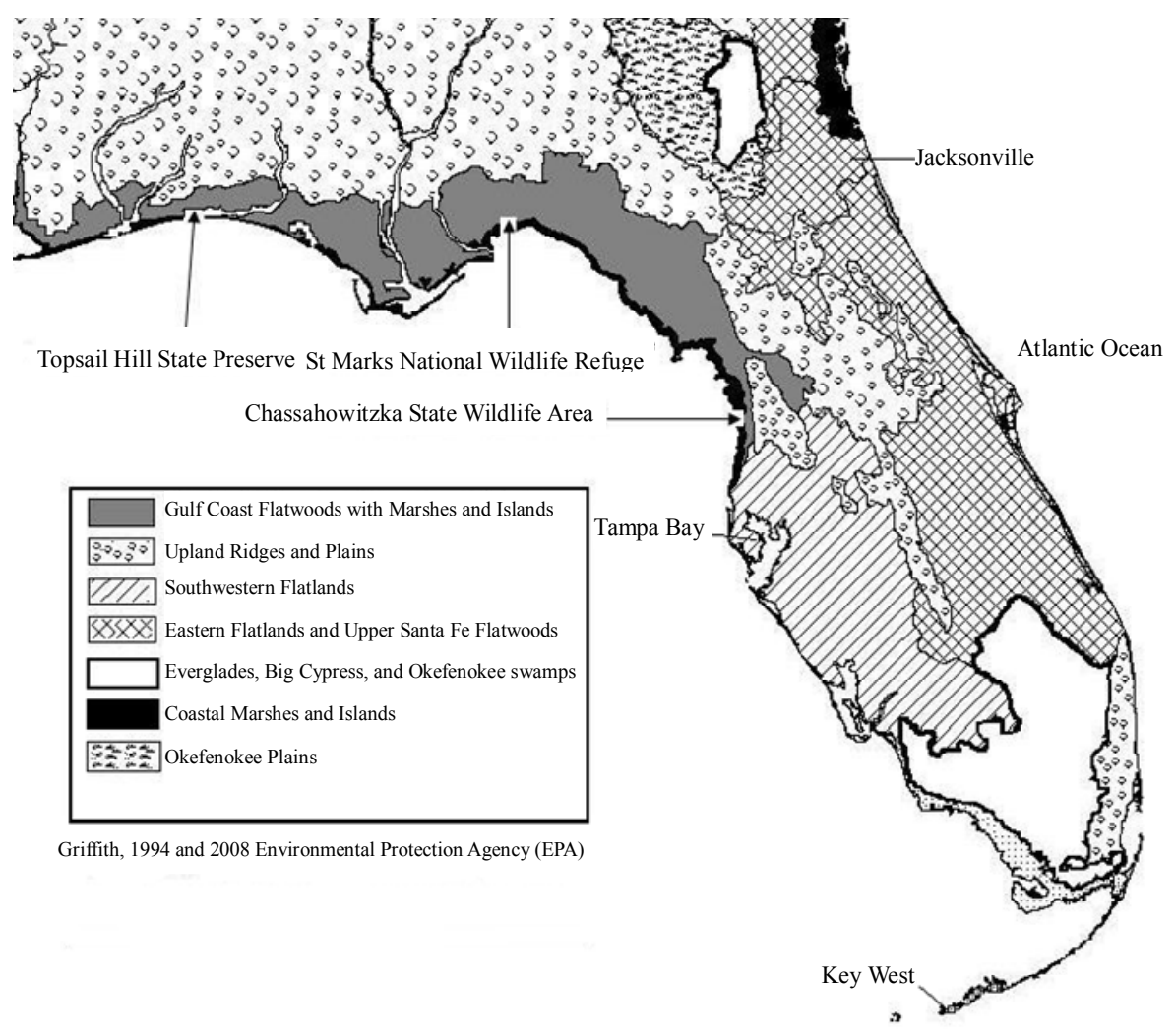

Figure 1. Locations of the three reference sites within the Gulf Coast Flatwoods subecoregion of Florida (Griffith et al. 1994, 2008).

been prescribed for more than 25 years at approximately a three-year-return interval. All of the sites are managed by a state or federal agency to enhance habitat for threatened species associated with longleaf pine ecosystems.

The southern reference site on the spatial gradient is the Chassahowitzka Wildlife Management Area $\left(28^{\circ} 78^{\prime} 47^{\prime \prime} \mathrm{N}, 82^{\circ} 34^{\prime} 26^{\prime \prime} \mathrm{W}\right)$ in Hernando County, FL. It is approximately 12,140 ha, and the soils are dominated by Myakka fine sands (sandy, siliceous, hyperthermic, aeric, alaquods) and Basinger fine sands (sandy, siliceous, hyperthermic spodic Psammaquents) [17,43]. Even though this site is found within the Big Bend Karst (75-06) subecoregion, its coastal location contain vegetation and soils with greater similarity to the other study sites located within the neighboring Gulf Coast Lowlands (7501) subecoregion $[42,43]$. The St. Marks National Wildlife Refuge $\left(30^{\circ} 6^{\prime} 18^{\prime \prime} \mathrm{N}, 85^{\circ} 11^{\prime} 7^{\prime \prime} \mathrm{W}\right)$ in Wakulla and Jefferson Counties, FL consists of 25,900 ha with the major soils being the Leon series (sandy, siliceous, thermic, aeric, alaquods) and the Scranton series (sandy, siliceous, thermic, humaqueptic, Psammaquents); [19,44]. Topsail Hill State Park $\left(30^{\circ} 22^{\prime} 15^{\prime \prime} \mathrm{N}, 86^{\circ} 16^{\prime} 20^{\prime \prime} \mathrm{W}\right)$ in Walton County, FL, contains 610 ha of some of the oldest longleaf pine stands in Florida. The park also contains important dune lake habitat. The soils are the Leon series and the Pickney sand series (sandy, siliceous, thermic, cumulic, humaquepts) $[18,45]$.

Pine patches representing differently aged cohorts up to 110-years of longleaf pine succession have been included as the temporal scale applied in this study. The reference site and chronosequencial scale were only determined after an in-depth field survey of stand conditions along Florida's Gulf Coast Flatwoods zone.

\subsection{Patch Age-Tree Size Classes}

The 110-year patch-derived chronosequence is based upon measuring the selected longleaf pine patches starting from six years after stand replacement to the oldest patches (cohort) measured within our reference sites. Each reference location contained three distinctly-aged pine forests (one-hectare blocks) where four randomly placed $400 \mathrm{~m}^{2}$ pine patches were measured from within each block. The patch size was based upon earlier longleaf pine flatwoods research which found the average gap size (cohort) to vary from $335-410 \mathrm{~m}^{2}$ within natural pine stands [46]. The three following age-tree size class descriptions based upon collected field data provided a means of tying patch age to stand structure $[39,47]$.

The young age-tree size class: A young age pine patch exists when at least $70 \%$ of the stocking is found as seedlings and saplings. Any minor pole component should 
have an average DBH less than $20 \mathrm{~cm}$. The mid-age-tree size class: The mid age pine patch exists when at least $70 \%$ of the stocking is dominated by a mixture of poles and small sawlog size trees $(10-30 \mathrm{~cm} \mathrm{DBH})$. The mature age-tree size class: A mature pine patch exists when at least $70 \%$ of the stocking is dominated by sawlog size trees (30 - $45 \mathrm{~cm} \mathrm{DBH).} \mathrm{For} \mathrm{this} \mathrm{study,} \mathrm{a} \mathrm{seedling} \mathrm{is} \mathrm{de-}$ fined as a woody plant that is generally less than $91.5 \mathrm{~cm}$ in height, while a sapling is a woody plant with a diameterat-breast height $(\mathrm{DBH})$ of less than $10 \mathrm{~cm}$ but greater than $2.5 \mathrm{~cm}$. Finally, a tree is defined as a woody plant with a DBH of greater than $10 \mathrm{~cm} \mathrm{[48].}$

\subsection{Data Collection}

In order to examine natural phenomena as they exist, we conducted a non-experimental comparative survey of the ecological attributes from within the three reference locations. Therefore, field data collection utilized a modified nested approach to correspond with the average pine patch size found in Florida's coastal natural longleaf pine flatwoods [46,49]. Each reference location had three one-hectare blocks, representing each of the three previously defined patch age-tree size classes. Each onehectare block contained four randomly placed $400 \mathrm{~m}^{2}$ patches (cohort) used to take measurements [39]. Patch size was based on earlier longleaf pine flatwoods research that found the average gap size to vary from 335 to $410 \mathrm{~m}^{2}$ in natural pine stands [46]. Tree height and DBH were measured on all trees greater than $10 \mathrm{~cm}$. All saplings were measured for height and diameter (root collar). Patch density (trees/ha), basal area (BA) $\left(\mathrm{m}^{2} / \mathrm{ha}\right)$ and standing volume $\left(\mathrm{m}^{3} / \mathrm{ha}\right)$ were calculated from these data. At least $30 \%$ of the representative trees were cored at breast height to determine patch age. The equation used for tree volume was: Volume $(\mathrm{V})=$

\section{$\left(0.000078539816 *\left(\mathrm{DBH}^{2}\right)\right) *$ tree height [48].}

Each $400 \mathrm{~m}^{2}$ measurement patch contained four $1-\mathrm{m}^{2}$ plots randomly nested within the larger patch for understory plant sampling. Stem counts and percent cover of each plant species were assessed using a modified Daubenmire method incorporating eight different coverages [49-51]. The list of species is found in the Species Code List (see Appendix A). Shannon-Weiner diversity values were calculated for each patch [52].

\subsection{Soil Sampling and Preparation}

Soil samples were taken from the top $10 \mathrm{~cm}$ within each $1 \mathrm{~m}^{2}$ vegetation quadrat and stored at $4{ }^{\circ} \mathrm{C}$ until analysis. Sub-samples $(20 \mathrm{~g})$ were analyzed for soil $\mathrm{pH}$ by prepared slurries using a soil-to-water ratio of 1-to-2 [53], percent organic matter (SOM) content by the WalkleyBlack method [54], and a sieved and dried $\left(105^{\circ} \mathrm{C}\right)$ subsample was used to determine gravimetric moisture con- tent. Net nitrogen mineralization rates $\left(\mathrm{N}_{\mathrm{MIN}}\right)$ were estimated from in-situ incubation of soil samples $[55,56]$. Soil microbial biomass carbon $\left(\mathrm{C}_{\mathrm{MB}}\right)$ was determined by chloroform fumigation-extraction [57].

\subsection{Statistical Analyses}

A three-level balanced nested plot design was incorporated into a stratified random sample in order to integrate the different ecosystem attributes measured at different scales, and among sites. Patches previous grouped by the three age-tree size classes were further stratified using the specific ages of the cohorts they contained into five distinct time intervals $(6-10,17-34,36-52,60-71,86$ - 110). This allowed us to analyze changes in forest structure and plant species composition from one time interval to the next $[58,59]$.

Since we conducted a non-experimental comparative survey of the ecological attributes of each site, the sampling of these nine distinct reference sites produced a dataset where the normality assumption needed for the analysis of variance (ANOVA) was not justified. Therefore, trends over time and between variables were obtained from linear polynomial regression using the general linear model [60]. The 2 nd order polynomial regression equation standard form is $\mathrm{y}=\mathrm{a}^{0}+\mathrm{a}^{1} \mathrm{x}+\mathrm{a}^{2} \mathrm{x}^{2}+\varepsilon$. Regression models were validated by comparing residuals with predicted values along normal Q-Q plots and comparing F-ratios to eliminate higher order terms. Models were also tested for multicollinearity by variance inflation factors and condition index numbers.

PC-ORD, a PC-based program [61] containing an algorithm for Canonical Correspondence Analysis (CCA) was used to examine the overall spatial structure of the individual reference patches by identifying the understory plant species along vectors (gradients) for soil chemical, net nitrogen mineralization, and soil microbial biomass values found among the study sites [62]. Linear combinations of the environmental variables were used to maximize the separation of plant species along four biplot axes. Site scores were derived from the weighted averages of the associated species scores. Community structure was illustrated by the influence of different environmental variables upon plant species ordination [63].

Plant species indicator analysis (IndVal) was used to measure the level of relationship between a given plant species to categorical units such as pine flatwoods subtypes or patch age intervals. It was also used to attribute different plant species to particular soil biogeochemical conditions based on the abundance and occurrence of those species within the selected group. Indicator values range from 0 to 100 , with " 100 " being a perfect indicator and " 0 " a no affiliation score. Because indicator species 
analysis is a statistical inference, the Monte Carlo permutation test procedure (1000 iterations) was used to establish significance of a $\mathrm{p}$-value as determined by the number of random runs greater than or equal to the inferred value $(\alpha=0.10)$. Accuracy was defined from the binomial 95\% confidence interval $[64,65]$. Hypothesis testing for differences between field data grouped by two soil drainage classes was accomplished by using two-sample t-test with an alpha of 0.05 and a two-tailed confidence interval. A Mixed model REML with F-ratios was used to determine the power of each collected field variable within the nested design along spatial and temporal scales [60].

\section{Results and Discussion}

\subsection{Soil Types}

All three sites contained taxonomically similar soil types. All of the soils had similar soil properties (sandy, acidic, thermic, aquic, and poorly drained). The soils were also found to be functionally equivalent $\left(\mathrm{N}_{\mathrm{MIN}}, \mathrm{C}_{\mathrm{MB}}\right.$ and $\left.\mathrm{BA}\right)$; even when compared by drainage class (Table 1). The only significant difference was soil organic matter content between poorly drained and very poorly drained soils.

\subsection{Overstory Stand Structure}

A total of 36 measured pine patches resulted in 26 differently aged cohorts along the chronosequence. Five distinct patch age intervals were identified by data analysis. They were Young (6 - 10 years), Young-Midaged (17 34 years), Midaged (36 - 53 years), Mid-Mature (60 - 71 years), and Mature (86 - 110 years). The mean patch $\mathrm{DBH}$, height, BA, and volume increased significantly among the five time intervals (Table 2). For example, the mean DBH for patches between 6 - 10 years after establishment was approximately $6.0 \mathrm{~cm}, 20-25 \mathrm{~cm}$ for the patches 35 - 52 years, and greater than $30.0 \mathrm{~cm}$ for the patches greater than 85 years (mature age). Height, BA, and volume exhibited similar results, even though stand density was highly variable with no identifiable temporal patterns (Table 2).

Polynomial regression analysis revealed all of the stand variables, except for stand density, increased with patch age. Patch mean DBH and height increased with age until they reached an asymptote at 85 - 90 yrs. Stand basal area and volume followed similar regression curves as with DBH and height (Figure 2). The diameter distribution of trees by patch age interval reflected the increase in diameter (Figure 3).

Table 1. Soil and stand properties between the three reference sites.

\begin{tabular}{|c|c|c|c|c|c|}
\hline Location & Soil Great Group & $\begin{array}{l}\text { Soil Texture (Top } \\
10 \mathrm{~cm})\end{array}$ & Moisture Regime & Temperature Regime & Drainage Class \\
\hline \multicolumn{6}{|l|}{$\begin{array}{c}\text { Chassahowitzka Wildlife } \\
\text { Management Area }\end{array}$} \\
\hline & Psammaquent & Sandy & Aquic & Hyperthermic & $\begin{array}{l}\text { Very poorly } \\
\text { drained }\end{array}$ \\
\hline & Alaquod & Sandy & Aquic & Hyperthermic & Poorly drained \\
\hline \multicolumn{6}{|c|}{$\begin{array}{c}\text { St. Marks National Wildlife } \\
\text { Refuge }\end{array}$} \\
\hline & Psammaquent & Sandy & Aquic & Thermic & $\begin{array}{l}\text { Very poorly } \\
\text { drained }\end{array}$ \\
\hline & Alaquod & Sandy & Aquic & Thermic & Poorly drained \\
\hline \multicolumn{6}{|l|}{ Topsail Hill State Preserve } \\
\hline & Humaquept & Sandy & Aquic & Thermic & $\begin{array}{l}\text { Very poorly } \\
\text { drained }\end{array}$ \\
\hline & Alaquod & Sandy & Aquic & Thermic & Poorly drained \\
\hline \multicolumn{6}{|c|}{ Stand Basal Area and Soil Biochemical Properties (Mean Values*) } \\
\hline Drainage Class & $\begin{array}{l}\text { Stand Basal Area } \\
\qquad\left(\mathrm{m}^{2} / \mathrm{ha}\right)\end{array}$ & $\mathrm{pH}-\log [\mathrm{H}+]$ & 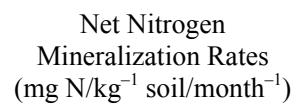 & $\begin{array}{l}\text { Microbial Biomass Carbon } \\
\quad\left(\mathrm{mg} \mathrm{C} \mathrm{kg}^{-1} \text { soil }\right)\end{array}$ & \\
\hline Very poorly drained & $6.5 \mathrm{a}$ & $4.4 \mathrm{a}$ & $11.6 \mathrm{a}$ & $374.3 \mathrm{a}$ & \\
\hline Poorly drained & $8.3 \mathrm{a}$ & $4.5 \mathrm{a}$ & $9.9 \mathrm{a}$ & $356.1 \mathrm{a}$ & \\
\hline
\end{tabular}

\footnotetext{
"Means between drainage classes followed by the same lower case letters are not significantly different (alpha $=0.05)$
} 
Table 2. Stand attributes and species richness by patch age interval.

\begin{tabular}{cccccccc}
\hline $\begin{array}{c}\text { Patch Age } \\
\text { Interval } \\
\text { (years) }\end{array}$ & Patch Age Class & $\begin{array}{c}\text { Mean Patch } \\
\text { Diameter }(\mathrm{cm})\end{array}$ & $\begin{array}{c}\text { Mean Patch } \\
\text { Height }(\mathrm{m})\end{array}$ & $\begin{array}{c}\text { Patch } \\
\text { Density } \\
(\text { trees/ha) }\end{array}$ & $\begin{array}{c}\text { Patch Basal Area } \\
\left(\mathrm{m}^{2} / \mathrm{ha}\right)\end{array}$ & $\begin{array}{c}\text { Patch Volume } \\
\left(\mathrm{m}^{3} / \text { ha }\right)\end{array}$ & $\begin{array}{c}\text { Shannon-Wiener } \\
\text { Diversity H' }\end{array}$ \\
\hline $6-10$ & Young & $5.1(0.53)$ & $2.5(0.32)$ & $258(20.1)$ & $0.12(0.02)$ & $9.3(0.10)$ & $1.96(0.05)$ \\
$17-34$ & Young/Mid & $19.1(0.77)$ & $10.2(0.25)$ & $293(20.0)$ & $6.81(0.48)$ & $75.5(5.59)$ & $2.07(0.05)$ \\
$36-52$ & Mid-Age & $25.5(1.04)$ & $15.4(0.80)$ & $211(30.4)$ & $8.56(1.21)$ & $138.3(22.61)$ & $1.75(0.06)$ \\
$60-71$ & Mid/Mature & $29.6(1.54)$ & $15.4(0.59)$ & $229(23.6)$ & $11.59(1.30)$ & $186.9(23.78)$ & $1.75(0.07)$ \\
$86-110$ & Mature & $29.9(1.2)$ & $16.6(0.46)$ & $190(8.7)$ & $11.83(0.46)$ & $214.3(6.91)$ & $1.44(0.04)$ \\
\hline
\end{tabular}

The sample size for stand data by age class was $n \geq 6$; and for the vegetation-soils data $n \geq 12$.
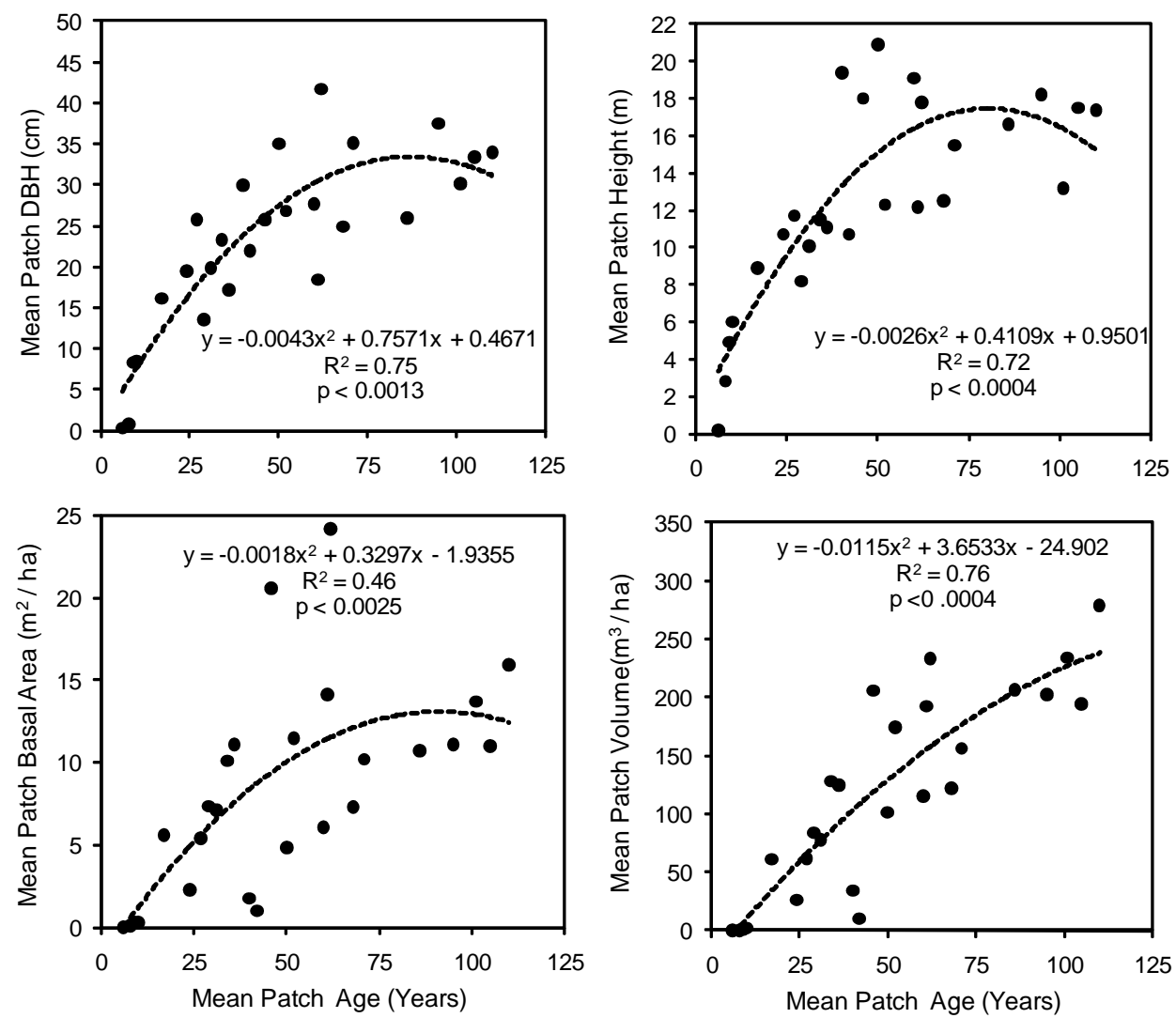

Figure 2. Mean stand DBH, height, BA, and volume along a 110-year longleaf pine chronosequence as measured from 26 differently aged pine patches.

\subsection{Understory Plants}

The three reference sites shared more than 45 plant species in common (Appendix A). The three most common understory species were Ilex glabra, Quercus pumila, and Serenoa repens. A species found in rare numbers among sites was Xyris caroliniana, a wetland indicator. The abundance of grasses and forbs decreased while the abundance of shrubs increased over the chronosequence ( $<<0.05$; Figure 4). The Shannon-Wiener diversity index decreased as patch age increased, while having a range from 2.07 - 1.44 for the dataset (Table 2; Figure 5).

\subsection{Site Classification}

Smilax pumila, Hypericum hypericoides, and Gaylussacia frondosa were the dominant plant species indicators for mesic flatwoods $(\mathrm{p} \leq 0.038)$, Aristida stricta var. beyrichiana, and Dichanthelium ovale were the dominant plant species indicators for the wet flatwoods subtype ( $p$ $\leq 0.001$ ), while Lachnanthes caroliniana and Scleria cilliata were the dominant plant species indicators for the wet savanna subtype ( $\mathrm{p} \leq 0.009$; Table 3 ). Twenty (20) patches were classified as mesic flatwoods, 7 patches as wet flatwoods, and 9 patches as wet savanna. 

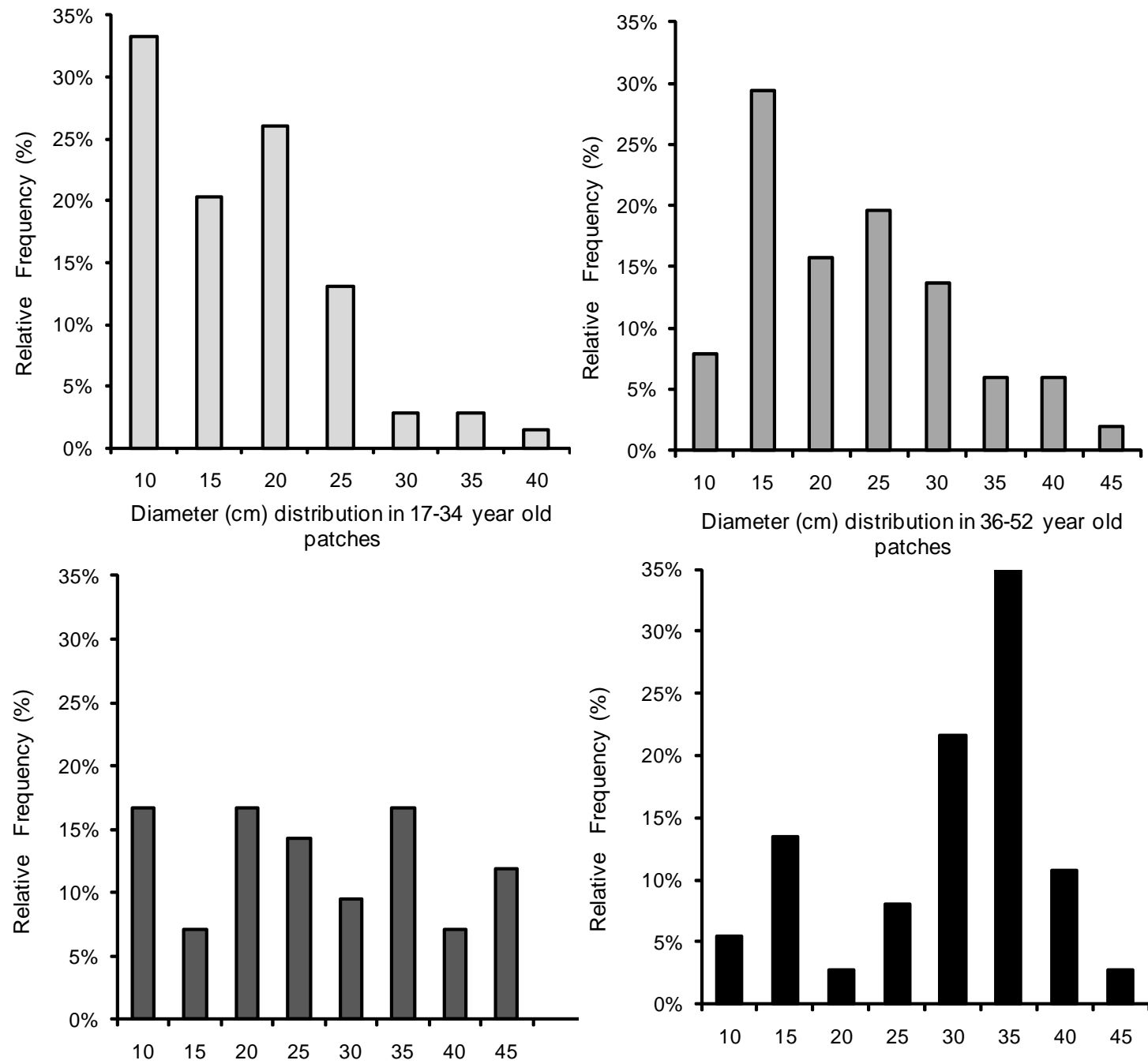

Diameter $(\mathrm{cm})$ distribution in 60-71 year old patches

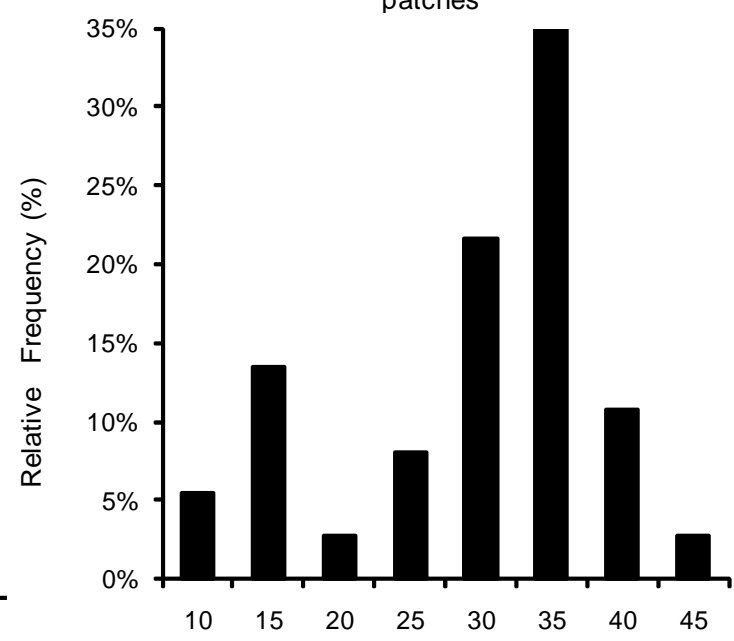

Diameter (cm) distribution in 86-110 year old patches

Figure 3. Diameter distribution of trees $10 \mathrm{~cm}$ d.b.h. and greater within the four patch age intervals as measured from 26 differently aged pine patches.

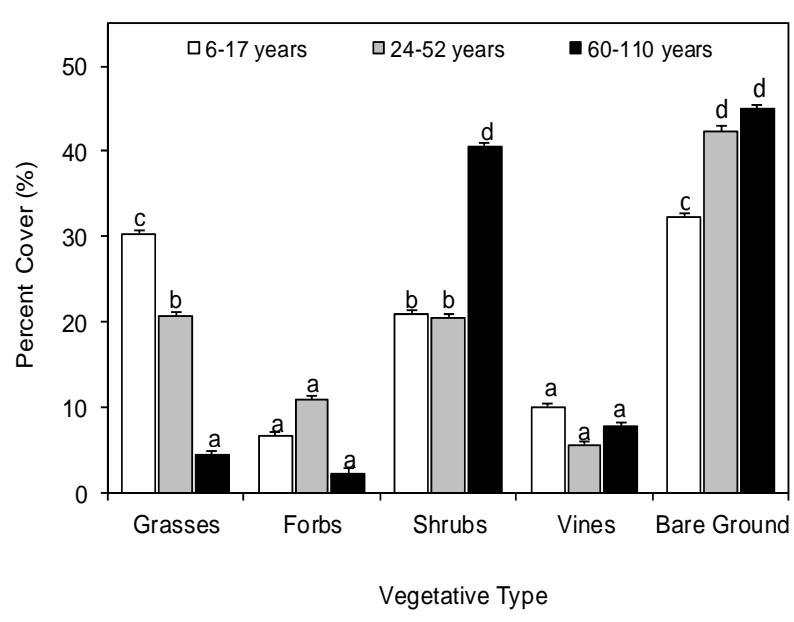

Figure 4. Composition of understory vegetation by patch age interval.

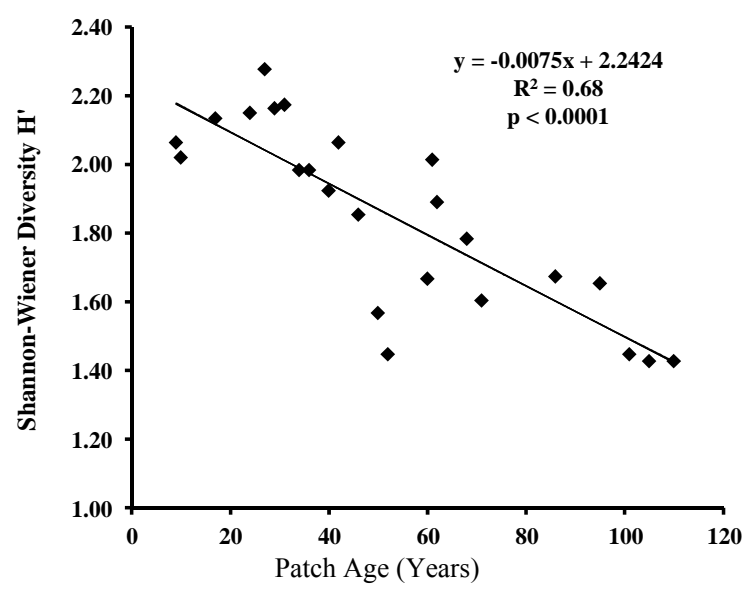

Figure 5. Shannon-Wiener Diversity index along a 110-year longleaf pine chronosequence as measured from 26 differently aged pine patches. 
Table 3. Plant indicator values (IndVal*) (percent of perfect indication) with associated environmental variable by pine flatwoods type. P-values represent the proportion of randomized runs (1000) equal to or less than observed values $(\alpha=0.1)$.

\begin{tabular}{|c|c|c|c|c|c|c|c|}
\hline \multirow{2}{*}{ Pine Subtype } & \multirow{2}{*}{ Plant Species } & \multicolumn{3}{|c|}{ Pine Subtype } & \multirow[b]{2}{*}{$\mathrm{SD}$} & \multirow[b]{2}{*}{ P-Value } & \multirow[b]{2}{*}{ Veg Type } \\
\hline & & Mesic & Wet Flatwoods & Wet Savanna & & & \\
\hline \multirow[t]{4}{*}{ Mesic Flatwoods } & Smilax pumila & 25 & 1 & 5 & 4.69 & 0.038 & Vine \\
\hline & Hypericum hypericoides & 17 & 1 & 0 & 3.08 & 0.024 & Forb \\
\hline & Gaylussacia frondosa & 16 & 0 & 4 & 3.3 & 0.057 & Shrub \\
\hline & Pteridium aquilinum & 12 & 0 & 1 & 3 & 0.066 & Fern \\
\hline \multirow[t]{4}{*}{ Wet Flatwoods } & Lachnanthes caroliana & 0 & 52 & 4 & 3.57 & 0.001 & Forb \\
\hline & Arisitida beyrichiana & 0 & 36 & 0 & 3.51 & 0.001 & Grass \\
\hline & Dichanthelium ovale & 6 & 36 & 7 & 4.41 & 0.007 & Grass \\
\hline & Cyperus ssp. & 1 & 11 & 1 & 2.67 & 0.088 & Grass \\
\hline \multirow[t]{2}{*}{ Wet Savanna } & Ilex glabra & 19 & 13 & 38 & 3.55 & 0.009 & Shrub \\
\hline & Scleria ssp. & 17 & 3 & 29 & 3.31 & 0.014 & Grass \\
\hline
\end{tabular}

*INDICATOR VALUES (\% of perfect indication based on combining the values for relative abundance and relative frequency) $\mathrm{n}=48$.

\subsection{Discussion}

There are four assumptions which must be met in order to insure the credible use of space-for-time substitutions (chronosequence) when studying ecosystem change [66]. They include having strong similarities in vegetative composition, soil properties, and climatic patterns, while sharing the same position in the landscape. There is also a need to have an extensive knowledge of the land-use history of each site. The use of a chronosequence to study secondary succession in coastal longleaf pine patches was justified given the close similarities (greater than 45 common species) in plant species composition, their almost identical soil properties found at each site, their location within the same climatic zone, their equivalent positions on the landscape, and the known 25 year landuse history of each reference site [67-69].

There were six major hurricanes which passed through our study sites during the 2004-2005 field seasons. The use of a strict coastline stratification proved to be effecttive at limiting the differences between the reference sites from the impacts of high winds and flooding on the forest canopies and soil properties of each site. The results on stand attributes, understory species diversity, and diameter distributions verify the effectiveness of the patch age intervals at stratifying the dataset (Table 2; Figure 3).

In response to criticisms against the use of the buried bag technique and the determination of field net mineralization rates instead of gross nitrogen fluxes [70,71], there was no need to determine the absolute (gross) levels of nitrogen uptake in this study. The wetland conditions of the sampled soils made the comparative measurement of ammonium more important then nitrate. When the purpose of the study is to compare similar forested wetland sites, it is perfectly justified to use poly- ethylene bags to determine the net nitrogen mineralization rates. The wetland conditions make the use of the ion exchange-resin bag technique very limited since the resin bags favor the collection of nitrate, and under estimate the levels of ammonium [70,72]. The use of polyethylene bags preserved the assessment of ammonium in saturated soils [73]. The plant uptake of nitrogen was less important since plants can compete for nitrate easier than they can for ammonium, which is the preferred source of nitrogen for microbes [74]. Wienhold (2007) found insitu estimates are more reflective of field conditions than either anaerobic estimates or laboratory incubations [75].

The overstory variables of mean patch $\mathrm{DBH}$, patch BA, volume, and to a lesser degree patch height exhibited strong positive relationships with the age of the pine patches between 6 - 110 years. But, patch tree density showed no clear pattern along the chronosequence, owing to the high variability found within the patches along Florida's Gulf. This is a reasonable result given the number of major hurricanes which impacted this landscape just prior to measurement. Patch tree density was continuously impacted by this disturbance regime during the life of the study. The ecological dataset showed most of the growth variables reaching an asymptote around 80 90 years. When the measured stand data from these pine patches was compared to growth and yield data from a group of thinned natural longleaf pine stands from across the eastern Gulf, our patches were found to have lower basal area $\left(14 \mathrm{~m}^{2}\right.$ vs. $\left.25 \mathrm{~m}^{2}\right)$ at age 30 , but comparable stand volumes $\left(150 \mathrm{~m}^{3}\right.$ vs. $\left.130 \mathrm{~m}^{3}\right)$ at age 60 [76]. Our restoration threshold of $80-90$ years was found to have a regional difference with the threshold age of 110 years for longleaf pine ecosystems in Texas, reported by Chapman (1909) [77].

Prescribed fire on a three year return-interval did not prevent shrub species from increasing or graminoid spe- 
cies from declining as the age of the pine patch increased. This result could be explained by lower intensive prescribed fires having less of an effect within the wet conditions encountered at our reference sites.

The vegetative and environmental variables collected from the reference sites were effective for ecologically classifying all of the patches. However, soil properties were stronger determinants of specific ecosystem conditions than were patch age determinations (Table 1; Figure 6).

\section{Conclusions}

All of the sites were found to have functionally equivalent soils and shared more than 40 plant species in common. Patch DBH, height, and basal area increased until 80 - 90 years when they reached a plateau. Shrub species were significantly higher in the mature-aged patches compared to either the young or mid-aged patches. These combined results infer that Florida's Gulf coastal wet longleaf pine flatwoods attain a structural and plant species equilibrium at approximately $80-90$ years. Soil biochemical properties, forest structure, and understory species composition were effective for ecologically classifying our pine patches as $55 \%$ mesic flatwoods, $20 \%$ wet flatwoods, and $25 \%$ wet savanna within Florida's highly disturbed Gulf coast.

One area of this research warrants further attention. Our research found that plant species classified as "shrubs" dominated the mature-aged stands even with aggressive fire management programs. Many of these "woody" plant species do not have pioneer patterns similar to Ilex

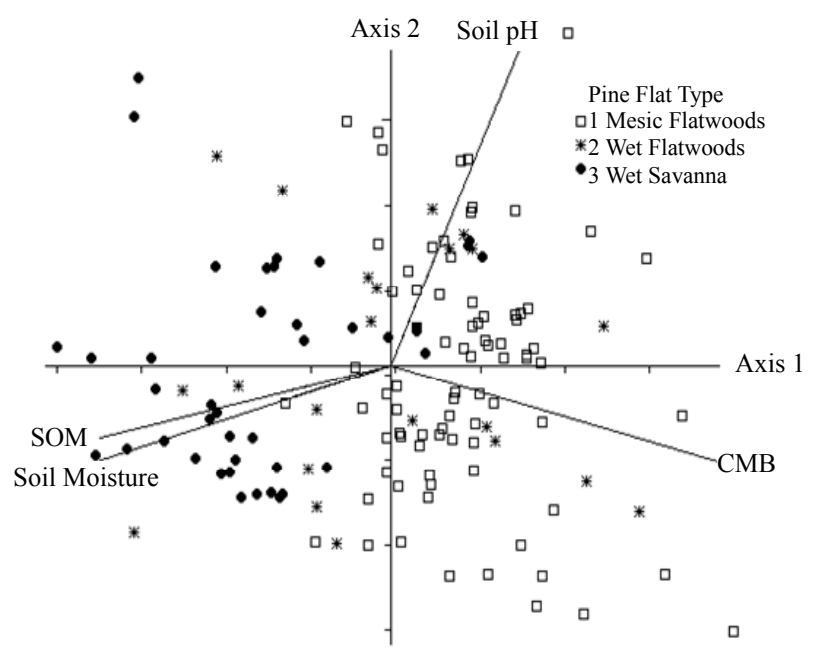

Figure 6. Pine flatwoods type determined by a four-dimensional ordination biplot derived from Canonical Correspondence Analysis (CCA) of 144 plots using understory plant species abundance and soil biogeochemical data (SOM, soil organic matter; CMB, microbial biomass carbon) from the three reference sites. glabra, Serenoa repens, or Quercus pumila. They never dominated the site. There should be studies that focus on these lesser known woody species and their possible benefits to mature longleaf pine forest ecosystems.

\section{Acknowledgements}

We would like to thank Leda Suydan \& Tom Ervin of Topsail Hill Preserve State Park, Joe Reinman of the St. Marks National Wildlife Refuge, and Mike Wichrowski \& Paul Hansen of the Chassahowitzka Wildlife Management Area of Florida's Fish \& Wildlife Commission for providing assistance with establishment of the reference sites and obtaining the research permits.

\section{REFERENCES}

[1] C. C. Frost, "History and Future of the Longleaf Pine Ecosystem" In: S. Jose, E. Jokela and D. L. Miller, Eds., The Longleaf Pine Ecosystem: Ecology, Silviculture, and Restoration, Springer Science+Business Media, LLC, New York, 2006, pp. 9-47.

[2] Wildlife Management Institute (WMI), "Regional Wildlife Habitat Needs Assessment for the 2007 Farm Bill: A Summary of Successes and Needs of Farm Bill Conservation Programs," WMI, Washington DC, 2006.

[3] America's Longleaf, "Range-Wide Conservation Plan for Longleaf Pine," Prepared by the Regional Working Group for America's Longleaf, 2009.

http://www.americaslongleaf.org/media/86/conservation plan.pdf

[4] R. K. Peet and D. J. Allard, "Longleaf Pine Vegetation of the Southern Atlantic and Eastern Gulf Coast Regions: A Preliminary Classification," Proceedings of the 18th Tall Timbers Fire Ecology Conference. The Longleaf Pine Ecosystem: Ecology, Restoration, and Management (1991), Tall Timbers Research Station, Tallahassee, Vol. 18, 1993, pp. 45-81.

[5] J. Walker, "Rare Vascular Plant Taxa Associated with the Longleaf Pine Ecosystems: Patterns in Taxonomy and Ecology," In: S. M. Hermann, Ed., Proceedings of Tall Timbers Fire Ecology Conference, Tall Timbers Research Station, Tallahassee, Vol. 18, 1993, pp. 105-130.

[6] D. G. Brockway and K. W. Outcalt, "Gap-Phase Regeneration in Longleaf Pine-Wiregrass Ecosystems," Forest Ecology and Management, Vol. 106, No. 2-3, 1998, pp. 125-139. doi:10.1016/S0378-1127(97)00308-3

[7] M. C. Sheffield, J. L. Gagnon, S. B. Jack and D. J. McConville, "Phenological Patterns of Mature Longleaf Pine (Pinus palustris M) under Two Different Soil Moisture Regimes," Forest Ecology and Management, Vol. 179, No. 1-3, 2003, pp. 157-167. doi:10.1016/S0378-1127(02)00523-6

[8] R. K. Myers and D. H. Van Lear, "Hurricane-Fire Interactions in Coastal Forests of the South: A Review and Hypothesis," Forest Ecology and Management, Vol. 103, No. 2-3, 1998, pp. 265-276. doi:10.1016/S0378-1127(97)00223-5 
[9] B. J. Palik, R. J. Mitchell and J. K. Hiers, "Modeling Silviculture after Natural Disturbance to Maintain Biological Diversity: Balancing Complexity and Implementation," Forest Ecology and Management, Vol. 155, No. 1-3, 2002, pp. 347-356. doi:10.1016/S0378-1127(01)00571-0

[10] J. A. Stanturf, S. L. Goodrick and K. W. Outcalt, "Disturbance and Coastal Forests: A Strategic Approach to Forest Management in Hurricane Impact Zones," Forest Ecology and Management, Vol. 250, No. 1-2, 2007, pp. 119-135. doi:10.1016/j.foreco.2007.03.015

[11] D. G. Brockway, K. W. Outcalt, D. J. Tomczak and E. E. Johnson, "Restoration of Longleaf Pine Ecosystems," General Technical Report SRS-83, US Forest Service, Southern Research Station, Ashville, 2005, 34 p.

[12] J. Walker and A. M. Silletti, "Restoring the Ground Layer of Longleaf Pine Ecosystems," In: S. Jose, E. Jokela and D. L. Miller, Eds., The Longleaf Pine Ecosystem: Ecology, Silviculture, and Restoration, Springer Science+Business Media, LLC, New York, 2006, pp. 297-333.

[13] P. C. Goebel, B. J. Palik, K. Kirkman, M. Drew, L. West and D. C. Pederson, "Forest Ecosystems of a Lower Gulf Coastal Plain Landscape: Multifactor Classification and Analysis," Journal of the Torrey Botanical Society, Vol. 128, No. 1, 2001, pp. 47-75. doi:10.2307/3088659

[14] M. W. LaSalle, "Recognizing Wetlands in the Gulf of Mexico Region: Regulatory Definition of Wetlands," Publication \# 2157 Extension Service of Mississippi State University, 2002, $25 \mathrm{p}$.

[15] P. J. Craul, J. S. Kush and W. D. Boyer, "Longleaf Pine Site Zones," General Technical Report SRS-89, US Department of Agriculture, Forest Service, Southern Research Station, Asheville, 2005, 23 p.

[16] W. H. McNab and P. E. Avers, "Ecological Subregions of the United States, Section Descriptions: Florida Coastal Lowlands (Western)," USDA Forest Service, Administrative Publication WO-WSA-5, 1994, 267 p.

[17] A. G. Hyde, L. Law, R. L. Weatherspoon, M. D. Cheyney and J. J. Eckenrode, "Soil Survey of Hernando County, Florida," Natural Resources Conservation Service, US Department of Agriculture, 1977, 152 p.

[18] J. D. Overing and F. C. Watts, "Soil Survey of Walton County, Florida," Natural Resources Conservation Service, US Department of Agriculture, 1989, 234 p.

[19] W. J. Allen, "Soil Survey of Wakulla County, Florida," U.S. Department of Agriculture, Soil Conservation Service, 1991, $163 \mathrm{p}$.

[20] R. B. Huck, "Plant Communities along Edaphic Continuum in a Central Florida Watershed," Florida Science, Vol. 50, 1987, pp. 111-128.

[21] L. K. Kirkman, R. Mitchell, R. C. Helton and M. Drew, "Productivity and Species Richness across an Environmental Gradient in a Fire-Dependent Ecosystem," American Journal of Botany, Vol. 88, No. 11, 2001, pp. 2119 2128. doi: $10.2307 / 3558437$

[22] M. G. Messina and W. H. Conner, "Southern Forested Wetlands: Ecology and Management," Lewis Publishers, New York, 1998, 616 p.
[23] Florida Natural Areas Inventory (FNAI), "Guide to the Natural Communities of Florida," 2010 Edition, Florida Natural Areas Inventory, Tallahassee, 2010, $215 \mathrm{p}$.

[24] R. L. Myers and J. J. Ewel, "Ecosystems of Florida," University of Central Florida Press, Orlando, 1990, 765 p.

[25] A. J. Parker and J. A. Hamrick. "Genetic Variation in Sand Pine (Pinus clausa)," Canadian Journal of Forest Research, Vol. 26, 1996, pp. 244-254. doi: $10.1139 / \mathrm{x} 26-028$

[26] J. S. Brewer, "Patterns of Plant Species Richness in a Wet Slash Pine (Pinus elliottii) Savanna," Journal of the Torrey Botanical Society, Vol. 125, No. 3, 1998, pp. 216-224. doi:10.2307/2997219

[27] J. S. Brewer, A. L. Cunningham, T. P. Moore, R. M. Brooks and J. L. Waldrup, "A Six Year Study of Fire Related Flowering Cues and Coexistence of Two Perennial Grasses in a Wet Longleaf Pine (Pinus palustris) Savanna," Plant Ecology, Vol. 200, No. 1, 2009, pp. 141154. doi:10.1007/s11258-008-9440-Z

[28] I. J. Stout and W. R. Marion, "Pine Flatwoods and Xeric Pine Forests of the Southern (Lower) Coastal Plain," In: W. H. Martin, S. G. Boyce and A. C. Echternacht, Eds., Biodiversity of the Southeastern United States, Lowland Terrestrial Communities, John Wiley and Sons, Inc., New York, 1993, pp. 373-446.

[29] W. R. Harms, W. M. Aust and J. A. Burger, "Wet Flatwoods," In: M. G. Messina and W. H. Conner, Eds., Southern Forested Wetlands: Ecology and Management, Lewis Publications, Boca Raton, 1998, pp. 422-444.

[30] J. A. Burger and Y. Xu, "Sustaining the Productivity and Function of Intensively Managed Forests," Final Project Report \# DE-FC07-97ID 13551, U.S. Department of Energy, Virginia Polytechnic Institute and State University, 2001, 38 p.

[31] L. K. Kirkman, "Impacts of Fire and Hydrological Regimes on Vegetation in Depression Wetlands of Southeastern USA," Tall Timbers Fire Ecology-Fire in Wetlands: A Management Perspective Conference Proceedings, Vol. 19, Tall Timbers Research Station, Tallahassee, 1995, pp. 10-20.

[32] S. T. A. Pickett and M. L. Cadenasso, "Landscape Ecology: Spatial Heterogeneity in Ecological Systems," Science, Vol. 269, No. 5222, 1995, pp. 331-334. doi:10.1126/science.269.5222.331

[33] L. E. Frelich, "Forest Dynamics and Disturbance Regimes," Cambridge University Press, Cambridge, 2002, 261 p. doi: $10.1017 / \mathrm{CBO} 9780511542046$

[34] J. M. Johnston and A. Crossley, "Forest Ecosystem Recovery in the Southeast US: Soil Ecology as an Essential Component of Ecosystem Management," Forest Ecology and Management, Vol. 155, No. 1-3, 2002, pp. 187-203. doi:10.1016/S0378-1127(01)00558-8

[35] J. S. Glitzenstein, D. R. Streng and D. D. Wade, "Fire Frequency Effects on Longleaf Pine (Pinus palustris Miller) Vegetation in South Carolina and Northeast Florida, USA," Natural Areas Journal, Vol. 23, 2003, pp. 2237.

[36] T. Redding, G. D. Hope, M. G. Schmidt and M. J. Fortin, 
"Analytical Methods for Defining Stand-Clearcut Edge Effects Demonstrated for Nitrogen Mineralization," Canadian Journal of Forest Research, Vol. 34, No. 5, 2004, pp. 1018-1024. doi:10.1139/x03-282

[37] D. H. Van Lear, W. D. Carroll, P. R. Kapeluch and R. Johnson, "History and Restoration of Longleaf PineGrassland Ecosystem: Implications for Species at Risk," Forest Ecology and Management, Vol. 211, No. 1-2, 2005, 150-165. doi:10.1016/j.foreco.2005.02.014

[38] P. F. Fulé, W. W. Covington and M. M. Moore, "Determining Reference Conditions for Ecosystem Management of Southwestern Ponderosa Pine Forests," Ecological Applications (ESA), Vol. 7, No. 3, 1997, pp. 895-908. doi:10.1890/1051-0761(1997)007[0895:DRCFEM]2.0.C $\underline{\mathrm{O} ; 2}$

[39] G. L. McCaskill, "Longleaf Pine (Pinus palustris Mill) Ecosystem Restoration on Coastal Wet Pine Flats: Developing a Monitoring Program Using Vegetation and Soil Characteristics," Ph.D. Dissertation, University of Florida, Gainesville, 2008.

http://ufdcimages.uflib.ufl.edu/UF/E0/01/60/63/00001/mc caskill_g.pdf

[40] R. R. Harris, "Defining Reference Conditions for Restoration of Riparian Plant Communities: Examples from California, USA," Environmental Management, Vol. 24, No. 1, 1999, pp. 55-63. doi:10.1007/s002679900214

[41] G. E. Griffith, J. M. Omemik, C. M. Rohm and S. M. Pierson, "Florida Regionalization Project," U.S. Environmental Protection Agency, National Health and Environmental Effects Research Laboratory, Corvallis, Oregon, EPA/600/Q-95/002, 1994, 83 p.

[42] G. E. Griffith and J. M. Omernik, "Ecoregions of Florida (EPA)," In: C. J. Cleveland, Ed., Encyclopedia of Earth, Environmental Information Coalition, National Council for Science and the Environment, Washington DC, Last revised 11 December 2008.

http://www.eoearth.org/article/Ecoregions_of_Florida_(E PA)

[43] S. Spencer, "Plant Communities of Chassahowitzka Wildlife Management Area," Division of Wildlife and Florida Natural Areas Inventory, Florida Fish and Wildlife Conservation Commission, 2004, $31 \mathrm{p}$.

[44] J. P. Reinman, "A Survey of the Understory Vegetation Communities of the St. Marks National Wildlife Refuge," Technical Report \# 41640-79-1, US Fish and Wildlife Service, 1985, $89 \mathrm{p}$.

[45] B. A. White, et al., "Topsail Hill Preserve State Park Unit Management Plan," Division of Recreation and Parks, Florida Department of Environmental Protection, 2000, $104 \mathrm{p}$.

[46] J. L. Gagnon, E. J. Jokela, W. K. Moser and D. F. Huber, "Characteristics of Gaps and Natural Regeneration in Mature Longleaf Pine Flatwoods Ecosystems," Forest Ecology and Management, Vol. 187, No. 2-3, 2004, pp. 373-380. doi:10.1016/j.foreco.2003.07.002

[47] A. Youngblood, T. Max and K. Coe, "Stand Structure in Eastside Old-Growth Ponderosa Pine Forests of Oregon and Northern California," Forest Ecology and Management, Vol. 199, No. 2-3, 2004, pp. 191-217. doi:10.1016/j.foreco.2004.05.056

[48] K. F. Wenger, "Forestry Handbook," 2nd Edition, Society of American Foresters, John Wiley \& Sons, New York, 1984, $1335 \mathrm{p}$.

[49] R. K. Peet, T. R. Wentworth and P. S. White, "A Flexible Multipurpose Method for Recording Vegetation Composition and Structure," Castanea, Vol. 63, 1998, pp. 262274.

[50] R. F. Daubenmire, "Canopy Coverage Method of Vegetation Analysis," Northwest Science, Vol. 33, 1959, pp. 4364.

[51] G. Spyreas and J. W. Mathews, "Floristic Conservation Value, Nested Understory Floras, and the Development of Second Growth Forests," Ecological Applications, Vol. 16, No. 4, 2006, pp. 1351-1366. doi:10.1890/1051-0761(2006)016[1351:FCVNUF]2.0.C $\underline{\mathrm{O} ; 2}$

[52] R. K. Colwell, "Estimates: Statistical Estimation of Species Richness and Shared Species from Samples," Version 8, 2006. http://viceroy.eeb.uconn.edu/estimates/

[53] E. O. McLean, "Soil pH and Lime Requirement," In: Methods in Soil Analysis, Part 2. Chemical and Microbiological Properties, 2nd Edition, Soil Science Society of America, Madison, 1982, pp. 199-244.

[54] A. Walkley, "A Critical Examination of a Rapid Method for Determining Organic Carbon in Soils: Effect of Variation in Digestion Conditions and of Inorganic Soil Constituents," Soil Science, Vol. 63, 1947, pp. 251-263. doi:10.1097/00010694-194704000-00001

[55] C. Eno, "Nitrate Production in the Field by Incubating the Soil in Polyethylene Bags," Soil Science Society American Journal, Vol. 24, No. 4, 1960, pp. 277-279. doi:10.2136/sssaj1960.03615995002400040019x

[56] D. R. Keeney and D. W. Nelson, "Nitrogen-Inorganic Forms," In: Methods in Soil Analysis, Part 2. Chemical and Microbiological Properties, 2nd Edition, Soil Science Society of America, Madison, 1982.

[57] E. D. Vance, P. C. Brookes and D. S. Jenkinson, "An Extraction Method for Measuring Soil Microbial Biomass Carbon," Soil Biology and Biochemistry, Vol. 19, No. 6, 1987, pp. 703-707. doi:10.1016/0038-0717(87)90052-6

[58] F. Müller, "Gradients in Ecological Systems," Ecological Modelling, Vol. 108, No. 1-3, 1998, pp. 3-21. doi:10.1016/S0304-3800(98)00015-5

[59] J. C. Aravena, M. R. Carmona, C. A. Perez and J. J. Armesto, "Changes in Tree Species Richness, Stand Structure and Soil Properties in a Successional Chronosequence in Northern Chiloe' Island, Chile," Revista Chilena de Historia Natural, Vol. 52, 2002, pp. 1-30.

[60] SAS Institute Inc., "SAS/STAT® 9.2 User’s Guide," SAS Institute Inc., Cary, 2008.

[61] B. McCune and M. J. Meffrod, "PC-ORD: Multivariate Analysis of Ecological Data," Version 4.0. MjM Software, Gleneden Beach, 1999.

[62] M. W. Palmer, "Putting Things in Even Better Order: The Advantages of Canonical Correspondence Analysis," Ecology, Vol. 74, No. 8, 1993, pp. 2215-2230. doi: $10.2307 / 1939575$ 
[63] C. J. F. Ter Braak, "Canonical Correspondence Analysis: A New Eigenvector Technique for Multivariate Direct Gradient Analysis," Ecology, Vol. 67, No. 5, 1986, pp. 1167-1179. doi:10.2307/1938672

[64] R. E. Strauss, "Statistical Significance of Species Clusters in Association Analysis," Ecology, Vol. 63, No. 3, 1982, pp. 634-639. doi:10.2307/1936782

[65] M. Dufrene and P. Legendre, "Species Assemblages and Indicator Species: The Need for a Flexible Asymmetrical Approach," Ecological Monographs, Vol. 67, 1997, pp. 345-366.

[66] E. A. Johnson and K. Miyanishi, "Testing the Assumptions of Chronosequences in Succession," Ecology Letters, Vol. 11, 2008, pp. 419-431. doi:10.1111/j.1461-0248.2008.01173.x

[67] B. L. Foster and D. Tilman, "Dynamic and Static Views of Succession: Testing the Descriptive Power of the Chronosequence Approach," Plant Ecology, Vol. 146, No. 1, 2000, pp. 1-10. doi:10.1023/A:1009895103017

[68] R. W. Myster and M. P. Malahy, "Is There a Middle Way between Permanent Plots and Chronosequences?" Canadian Journal of Forest Research, Vol. 38, 1998, pp. 3133-3138.

[69] L. R. Walker, D. A. Wardle, R. D. Bardgett and B. D. Clarkson, "The Use of Chronosequences in Studies of Ecological Succession and Soil Development," Journal of Ecology, Vol. 98, 2010, pp. 725-736. doi:10.1111/j.1365-2745.2010.01664.x

[70] D. Binkley, "Ion Exchange Resin Bags: Factors Affecting Estimates of Nitrogen Availability," Soil Science Society American Journal, Vol. 48, No. 5, 1984, pp. 1181-1184. doi:10.2136/sssaj1984.03615995004800050046x
[71] R. F. Powers, "Biomass Nitrogen Mineralization along an Altitudinal Gradient: Interactions of Soil Temperature, Moisture, and Substrate Quality," Forest Ecology and Management, Vol. 30, No. 1-4, 1990, pp. 19-29. doi:10.1016/0378-1127(90)90123-S

[72] M. F. Isaac and V. R. Timmer, "Comparing in-Situ Methods for Measuring Nitrogen Mineralization under Mock Precipitation Regimes," Canadian Journal of Soil Science, Vol. 87, No. 1, 2007, pp. 39-42. doi:10.4141/S06-024

[73] G. B. Noe, "Measurement of Net Nitrogen and Phosphorus Mineralization in Wetland Soils Using a Modification of the Resin-Core Technique," Soil Science Society American Journal, Vol. 75, 2011, pp. 760-770.

[74] D. Wedin and D. Tilman, "Competition among Grasses along a Nitrogen Gradient: Initial Conditions and Mechanisms of Competition," Ecological Monographs, Vol. 63, No. 2, 1993, pp. 199-229. doi:10.2307/2937180

[75] B. J. Wienhold, "Comparison of Laboratory Methods and an in Situ Method for Estimating Nitrogen Mineralization in an Irrigated Silt-Loam Soil," Communications in Soil Science and Plant Analysis, Vol. 38, No. 13-14, 2007, pp. 1721-1732. doi:10.1080/00103620701435498

[76] R. M. Farrar, "Volume and Growth Predictions for Thinned Even-Aged Natural Longleaf Pine Stands in the East Gulf Area," USDA Forest Service, Research Paper SO-220, Southern Forest Experiment Station, New Orleans, 1985, $171 \mathrm{p}$.

[77] H. H. Chapman, "A Method of Studying Growth and Yield of Longleaf Pine Applied in Tyler County, Texas," Proceedings: Society of American Foresters National Convention, Vol. 4, 1909, pp. 207-220. 


\section{Appendix A}

Species Code List

Table A-1. Species list.

\begin{tabular}{|c|c|c|}
\hline Scientific name & Code & Common name \\
\hline \multicolumn{3}{|l|}{ Shrubs } \\
\hline Asiminaincana & Asin & Wooly paw paw \\
\hline Cyrillaracemiflora & Cyra & Titi \\
\hline Gaylussaciadumosa & Gadu & Drawf huckleberry \\
\hline Gaylussacia frondosa & Gafr & Dangleberry \\
\hline Ilex coriacea & Ilca & Large gallberry \\
\hline Ilex glabra & Ilg1 & Gallberry \\
\hline Ilex vomitoria & Ilvo & Yaupon \\
\hline Kalmia hirsuta & Kahi & Hairy wicky \\
\hline Licaniamichauxii & Limi & Gopher apple \\
\hline Lyonia lucida & Lylu & Fetterbush \\
\hline Magnolia virginiana & Mavi & sweet bay \\
\hline Myricacerifera & Myce & Wax myrtle \\
\hline Photiniapyrifolia & Phpy & Red choke berry \\
\hline Quercus pumila & Qupu & Running oak \\
\hline Serenoa repens & Sere & Saw palmetto \\
\hline Stillangiasylvatica & Stsy & Queens delight \\
\hline Vacciniumspp. & Vace & Blueberry spp \\
\hline \multicolumn{3}{|l|}{ Grasses } \\
\hline Andropogon virginicus & Anvi & Bluestem grasses \\
\hline Aristida stricta var. beyrichiana & Arbe & Wiregrass \\
\hline Calamovilfacurtissii & $\mathrm{Cacu}$ & Curtis sandgrass \\
\hline Cteniumaromaticum & Ctar & Toothache grass \\
\hline Cyperus & Cype & Sedge spp \\
\hline Eragrostisspectabilis & Ersp & Purple lovegrass \\
\hline Dichanthelium ovale & Dich & Eggleaf witch grass \\
\hline Panicum - Dichanthelium & Pani & Panicumspp \\
\hline Dichantheliumerectifolium & Paer & Erect leaf witchgrass \\
\hline Panicumlaxiflorum & Pala & Velvet Witchgrass \\
\hline Scleriassp. & Scle & Nutrushspp \\
\hline Xyris caroliniana & Xyca & Yellow eyed grass \\
\hline \multicolumn{3}{|l|}{ Forbs } \\
\hline Asclepiasviridula & Asvi & Southern milkweed \\
\hline Aster adnatus & Asad & Scaleleaf aster \\
\hline Aster eryngiifolius & Aser & Thistleleaf aster \\
\hline Aster reticulatus & Asre & White top aster \\
\hline Aster tortifolius & Asto & Dixie aster \\
\hline Carphephorouspseudoliatris & Caps & Bristleleafchaffhead \\
\hline Carphephorusodoratissimus & Caod & Deer tongue \\
\hline Chrysopsis & Chry & Silkgrassspp \\
\hline Conyzacanadensis & Coca & Canadian horseweed \\
\hline
\end{tabular}




\section{Continued}

\begin{tabular}{|c|c|c|}
\hline Coreopsis linifolia & Coli & Texas tickseed \\
\hline Desmodiumrotundifolium & Dero & Tricklyfoil \\
\hline Droseracapillaris & Drca & Pink sundew \\
\hline Elephantopustomentosus & Elto & Devils grandmother \\
\hline Eupatorium capillifolium & Euca & Dog fennel \\
\hline Eupatorium compositifolium & Euco & Yankee weed \\
\hline Eupatoriummohrii & Eumo & Mohr's thoroughwort \\
\hline Eupatoriumpilosum & Eupi & Rough Boneset \\
\hline Euthamiagraminifolia & Eugr & Flat top goldenrod \\
\hline Gelsemiumsempervirens & Gese & Yellow jessamine \\
\hline Gratiolahispida & Grhi & Rough Hedgehyssop \\
\hline Hypericum hypericoides & Hyhy & St. Andrews cross \\
\hline Hypoxissessilis & Hyse & Glossyseed yellow stargrass \\
\hline Hyрохіsspp. & Нyро & Stargrassspp \\
\hline Lachnanthes caroliniana & Laca & Carolina redroot \\
\hline Lachnocaulon anceps & Laan & Whitehead bogbutton \\
\hline Lecheapulchella & Lepu & Leggett's pineweed \\
\hline Liatrisgracilis & Ligr & Slender gayfeather \\
\hline Liatristenuifolia & Lite & Shortleaf gayfeather \\
\hline Mimosa quadrivalvis & Miqu & Sensitive brier \\
\hline Oenotherafruticosa & Oefr & Evening primrose \\
\hline Opuntiahumifusa & Ophu & Prickly pear \\
\hline Pityopsisgraminifolia & Pigr & Silkgrass \\
\hline Pterocaulonpycnostachyum & Ptpy & Blackroot \\
\hline Rhexia alifanus & Rhal & Meadow beauty \\
\hline Rhexiapetiolata & Rhpe & Fringed meadow beauty \\
\hline Sabatiabrevifolia & Sabr & Shortleaf Rosegentian \\
\hline Seymeriacassioides & Seca & Yaupon Blacksenna \\
\hline Smilax laurifolia & Smla & Laurel green brier \\
\hline Smilax pumila & Smpu & Green brier \\
\hline Solidago odora & Sood & goldenrod \\
\hline Stylismapatens & Stpa & Coastal plain dawn flower \\
\hline Tragiaurens & Trur & Wavyleafnoseburn \\
\hline Verbena brasiliensis & Vebr & Brazilian vervain \\
\hline Viola septemloba & Vise & Blue violet \\
\hline Vitisrotundifolia & Viro & Muscadine \\
\hline
\end{tabular}

